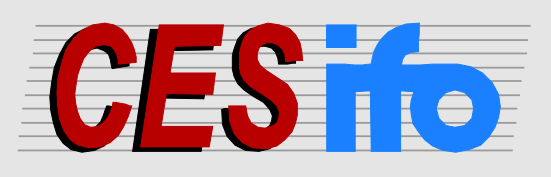

\title{
Working
}

Papers

\section{Monetary Policies of Large Industrialised Countries, Emerging Market Credit Cycles and Feedback Effects}

\author{
Andreas Hoffmann \\ Gunther Schnabl
}

\author{
CESIFO WORKING PAPER NO. 4723 \\ CATEgory 7: MONETARY POLICY AND INTERNATIONAL FinANCE \\ MARCH 2014
}
An electronic version of the paper may be downloaded
- from the SSRN website: Www.SSRN.com
- from the RePEc website: Www.RePEc.org
- from the CESifo website: www.CESifo-group.org/wp

\section{CESifo}




\title{
Monetary Policies of Large Industrialised Countries, Emerging Market Credit Cycles and Feedback Effects
}

\begin{abstract}
This paper explores the link between monetary policies of large industrial countries and international credit cycles. Based on an overinvestment framework, we show that in the prevailing asymmetric world monetary system, monetary policies of large centre countries can fuel credit booms in emerging markets. We argue that the absorption of inflationary pressure by emerging markets during boom periods as well as the fear of feedback effects of crises in emerging markets encourage delayed monetary tightening in centre countries. The paper helps explain asymmetric monetary policy patterns in centre countries and why the current global low interest rate environment is likely to prevail.
\end{abstract}

JEL-Code: E420, E580, F330, F440.

Keywords: asymmetric world monetary system, credit cycles, monetary policy, financial crisis, contagion.

\author{
Andreas Hoffmann \\ University of Leipzig \\ Grimmaische Str. 12 \\ Germany - 04109 Leipzig \\ ahoffmann@wifa.uni-leipzig.de
}

Gunther Schnabl

University of Leipzig

Grimmaische Str. 12

Germany-04109 Leipzig

schnabl@wifa.uni-leipzig.de 
The recent tapering of quantitative easing in the US has triggered instability in a set of emerging markets, including economic heavyweights such as India, Turkey, South Africa and Brazil. Falling markets could initiate a wave of contagion across the emerging world, with possibly severe feedback effects on the still fragile financial system of the large industrialised countries. Similarly, the 1997/1998 Asian crisis had triggered the Japanese financial crisis, which forced the Bank of Japan into its still continuing zero interest rate policy. The European Central Bank keeps postponing the exit from its low interest rate and unconventional monetary policy due to the sluggish economic recovery in the southern European crisis countries.

The monetary policies of the large industrialised countries at the centre of the world monetary system (particularly US, Japan and euro area) have been designed to fit domestic needs such as inflation and growth (Taylor 1993). In this spirit, prominent central bankers continue to use low levels of domestic consumer price inflation as primary measure of monetary policy success (Bernanke 2014, Draghi 2014). Yet in an asymmetric world monetary system, the monetary policies of the large central banks at the centre have a farreaching impact on the macroeconomic development of the periphery countries, with feedback effects on the industrialised countries themselves.

In the 1930s, Hayek (1937 [1989]) stressed that purely nationally oriented monetary policies had contributed to the beggar-thy-neighbour policies that were followed by economic disintegration, sluggish growth and political instability. More recently, McKinnon (2013) created the notion of an 'unloved dollar standard', which exports financial instability to the emerging markets. In line with this, Borio and Disyatat (2011) found that the world's low funding interest rates in the 2000s contributed to credit booms and financial imbalances on a global scale. While China has called for a new international monetary system that is less 
dependent on the US monetary policy (Xiaochuan 2009), Stokes (2014) suggested that "dollar hegemony" has even increased since the crisis.

This paper explores the link between monetary policies of large industrial countries and unsustainable credit booms in emerging market economies. While the previous literature mainly analysed the impact of the monetary policies of industrialised economies on emerging markets, we particularly focus on the feedback effects of credit booms and financial instability in emerging markets on monetary policy decisions in the centre countries of the world monetary system.

Based on an augmented overinvestment framework, our study shows that during the boom period of the 2000s, central banks in industrialised economies postponed monetary tightening, as emerging markets tended to absorb inflationary pressure. Furthermore, we illustrate that the subsequent crises in emerging markets, or the fear thereof, provide grounds for hesitant monetary tightening and further interest rate cuts. Based on our analysis, we derive asymmetric monetary policy patterns and the lock-in effects of low interest rate policies in the large industrialised countries that help explain why a decisive exit from the current low interest rate environment has become unlikely.

\section{$2 \quad$ Asymmetric Monetary Policy in the Large Industrial Countries}

The monetary overinvestment theories by Hayek (1929 [1976]) and Mises (1912) are used as a framework to define the possible role of monetary policy in the boom and bust in financial markets. This framework helps to derive asymmetric monetary policy patterns in the large industrialised countries that have brought short-term interest towards zero and have contributed to inflating central bank balance sheets. 


\subsection{Monetary Policy and Domestic Financial Market Booms}

Based on the monetary overinvestment theories by Mises (1912) and Hayek (1929 [1976]), three interest rates can be distinguished. First, the central bank interest rate is the interest rate that the central bank charges commercial banks for refinancing operations. Second, the capital market interest rate is the interest rate set by the private banking (financial) sector for credit provided to private households and enterprises. Third, the natural interest rate balances supply (savings $[\mathrm{S}]$ ) and demand (investment $[\mathrm{I}]$ ) on domestic capital markets $(\mathrm{I}=\mathrm{S})$. It is a theoretical concept that cannot be empirically observed. ${ }^{1}$ The savings-investment decisions in an economy are assumed to be in equilibrium when the natural rate of interest is equal to the central bank and capital market interest rates.

In the monetary overinvestment theories, a credit cycle begins with a fall of the capital market rate below the natural rate. This situation can be caused by a central bank that aims at stimulating economic activity via the Phillips curve effect by lowering the central bank ${ }^{2}$ interest rate (see for instance, Garrison 2004 and Huerta de Soto 2009). The fall in the central bank rate allows for easy refinancing conditions, with the capital market rate falling as well. As the natural interest rate stays unchanged, the capital market rate and natural interest rate diverge.

The falling capital market rate triggers additional investment. With consumption being expected to decline in the present and to increase in the future, high future returns on investment in capital goods (which aim at producing consumer goods in the future) are expected (Mises 1912, pp. 430-432; Hayek 1929 [1976], p. 101). This scenario constitutes an unsustainable disequilibrium between planned savings and investment. ${ }^{3}$ An overinvestment

\footnotetext{
${ }^{1}$ Most recently, in the context of (close to) zero central bank rates, a controversial discussion has emerged whether the natural interest rate can be negative. See e.g. von Weizsäcker (2011) or Summers (2013).

${ }^{2}$ Alternatively, Hayek (1929 [1976], p. 83) stressed the crucial role of the elasticity of the credit system in the emergence of credit cycles.

${ }^{3}$ Garrison (2004) modelled the distortionary effects of monetary policy on the production structure with the help of production possibility frontiers and the Hayekian triangle.
} 
boom in the capital goods sector is induced, which draws unemployed capacities and labour into the production of investment goods.

Rising employment, wages and income stimulate consumption. Given low interest rates, the demand for consumer goods - particularly durable goods - rises as well. Growing aggregate demand provides an incentive to further increase capacities (Garrison 2004). The positive expectations can be transmitted to asset markets, as profit expectations of enterprises have increased. Speculation may set in, and price expectations for stocks and other real assets can be disconnected from real economic development. ${ }^{4}$

The turnaround is either triggered by the central bank, when interest rates are lifted in response to rising inflation, or by the banking sector, when credit conditions are tightened because of changing sentiment concerning the sustainability of the upswing. Investment projects, with expected returns below the increased capital market rate, have to be dismantled. Asset prices start to decline; the equity positions and credit worthiness of enterprises fall.

As investment drops, the natural interest rate is pulled below the central bank and the capital market rates (which are kept high). A savings overhang emerges, with savings being more lucrative at relatively higher interest rates. In contrast, investment and output decline. Unused capacities and unemployment rise, while wages fall. With falling consumption (at higher interest rates), prices start to deflate. The process of dismantling low-return investment projects - the 'cleansing effect' in Schumpeter's (1934) words - goes within falling wages and prices, which is the basis for economic recovery.

\subsection{Identifying Monetary Policy Mistakes}

The monetary overinvestment theories of Hayek (1929 [1976]) and Mises (1912) allow the identification of two types of monetary policy mistakes. First, during an economic upswing,

\footnotetext{
4'The symptoms of prosperity themselves finally become, in the well-known manner, a factor of prosperity' (Schumpeter 1934, p. 226).
} 
the central bank keeps the central bank rate below the natural interest rate (type 1 monetary policy mistake), triggering an unsustainable overinvestment boom. Although over the past three decades, overinvestment booms in the narrow sense of the monetary overinvestment theories could hardly be observed, several authors linked benign liquidity conditions to boomand-bust cycles in financial markets.

Revankar and Yoshino (2008) argued that for Japan a low interest rate in response to the post-1985 Plaza appreciation contributed to undue credit growth and the 1986-1989 bubble in the Japanese real estate and stock markets. Taylor (2009) saw the monetary policy stance by the Federal Reserve under Alan Greenspan at the core of the exuberance in the US real estate market after the turn of the millennium. He showed that the federal funds rate was set substantially below the benchmark, as defined by the Taylor rule (Taylor 1993).

Schnabl and Wollmershäuser (2013) provide empirical evidence that the post-2001 low interest rate policies of the European Central Bank (paired with expansionary fiscal policies of the later crisis countries) can be viewed as the origin of unsustainable real estate and consumption booms in parts of the euro area and beyond, for instance in Central and Eastern Europe.

Second, during a downswing, the central bank keeps the interest rate too high, aggravating the economic downturn (type 2 monetary policy mistake). With respect to Japan, Posen (2000) classified as a policy mistake the Bank of Japan's attempt to contain the bubble economy with interest rate increases starting from 1988 and to deflate the bubble by keeping interest rates high, even after the bubble had burst. Bernanke (2000) dubbed the Japanese post-bubble stagnation of the 1990s as a 'self-induced paralysis', which could have been avoided by decisive interest rate cuts and 'unconventional monetary policy measures' such as outright purchases of government bonds and discretionary currency depreciation.

Friedman and Schwartz (1963), as well as Bernanke (2014), stressed that the Federal Reserve System's tight monetary policy during the Great Depression of the 1930s strongly 
aggravated the downturn. During the current European financial and debt crisis, a conflict within the European Monetary Union (EMU) has emerged. In Germany, the interest rate set by the European Central Bank is regarded as too low, whereas the majority of EMU member states see benign liquidity as a condition for a lasting economic recovery.

\subsection{Asymmetric Monetary Policy Patterns}

In practice, it seems that the two types of policy mistakes have been incorporated in different ways into monetary policy making since the mid-1980s. Central banks have tended to keep interest rates low during boom periods, as consumer price inflation has remained widely contained in a period dubbed as the Great Moderation (Bernanke 2004). Domestic financial market booms have been regarded as outside the responsibility of central banks, since central banks have been considered as unable to spot bubbles and/or to target price developments on specific financial market segments (Blinder \& Reis 2005). ${ }^{5}$ According to Bernanke and Gertler (2001, p. 253) central banks should respond to asset prices 'only to the extent that they affect the central bank's forecast of inflation'. As a result, central banks have tended to keep interest rates low for long periods during financial market booms, possibly becoming subject to type 1 monetary policy mistakes.

In contrast, given the Japanese experience with monetary tightening in response to the bursting bubble and the tight monetary policies pursued by the Federal Reserve in the early years of the Great Depression, interest rates came to be slashed in the face of financial crisis to avoid type 2 monetary policy mistakes. In the so-called 'Jackson Hole consensus', US central bankers agreed that central banks do not have sufficient information to spot bubbles, but should intervene in times of financial turmoil (Blinder \& Reis 2005).

This created a situation where financial markets could expect a quasi-bailout via interest rate cuts in times of crisis, the so-called 'Greenspan put' (Stiglitz 2010). Given the

\footnotetext{
${ }^{5}$ Mishkin (2008) viewed regulation as the adequate tool to control possible asset market bubbles.
} 
rising sensibility of central banks concerning financial stability during a crisis, they may even have tended to transform type 2 policy mistakes into type 1 policy mistakes. Central bank rates may have fallen below the natural interest rate, which would have balanced savings and investment during the crisis.

There are three possible reasons for too expansionary monetary policies during a crisis. First, in times of financial panic, the central bank has incomplete information concerning the degree of financial instability and assumes the natural interest rate to be lower than it actually is. Second, central banks make a correct assessment of the natural interest rate, but there is no clear institutional separation between the financial sector and the central bank. The central bank sets interest rates too low to minimise the losses of the financial sector. Third, the central bank is dependent on the government and increases the probability of incumbent public officials' re-election by minimising unemployment and government deficits. $^{6}$

The outcome has been asymmetric monetary policy patterns. Central bank interest rates have declined more during the crisis period than they have been lifted during the succeeding recovery. As shown in Figure 1, the average short-term interest rates in the large industrialised countries (Japan, US, Germany/euro area) have declined gradually from a level of about $12 \%$ in the early 1980 s to close to zero since the outbreak of the US subprime crisis. In Japan, where financial market exuberance had occurred much earlier than in the US and Europe, the money market interest rate had already reached the zero-bound in $1999 .^{7}$

\footnotetext{
${ }^{6}$ Buchanan and Wagner (1977 [1999], p. 120) argued 'that the actions of the Federal Reserve Board have not been independent of the financing needs of the federal government. Our hypothesis is that political pressures also impinge on the decisions of monetary authorities'.

${ }^{7}$ This does not necessarily imply that the structural decline of G3 interest rates originated in Japan. Moreover, it can be argued that the Federal Reserve had the largest degree of freedom in monetary policy decision making, which became transmitted via the exchange rate on Japanese monetary policy. Since the early 1980s, Japan's interest rate level had tended to remain lower than that of the US because of Japan's structural current account surpluses, rising foreign currency-denominated net international assets and thereby persistent appreciation expectations of the Japanese yen. Under this condition, a structural decline of the US interest rate would push Japanese interest rates towards zero (see Goyal \& McKinnon 2003).
} 
After the scope for interest cuts reached zero, the central bank balance sheets have been inflated by unconventional monetary policy measures, pioneered by the Bank of Japan (Iwata \& Takenaka 2011). These measures focus on purchases of government bonds of overindebted countries (to further depress interest rates at the long end of the yield curve) and bad assets from ailing financial institutions. Figure 2 shows the dramatic inflation of the balance sheets of the Bank of Japan since the mid-1990s, followed by those of the Federal Reserve Bank and the European Central Bank since 2007/2008.

\section{Figure 1: G3 Short-Term Interest Rates (Arithmetic Average)}

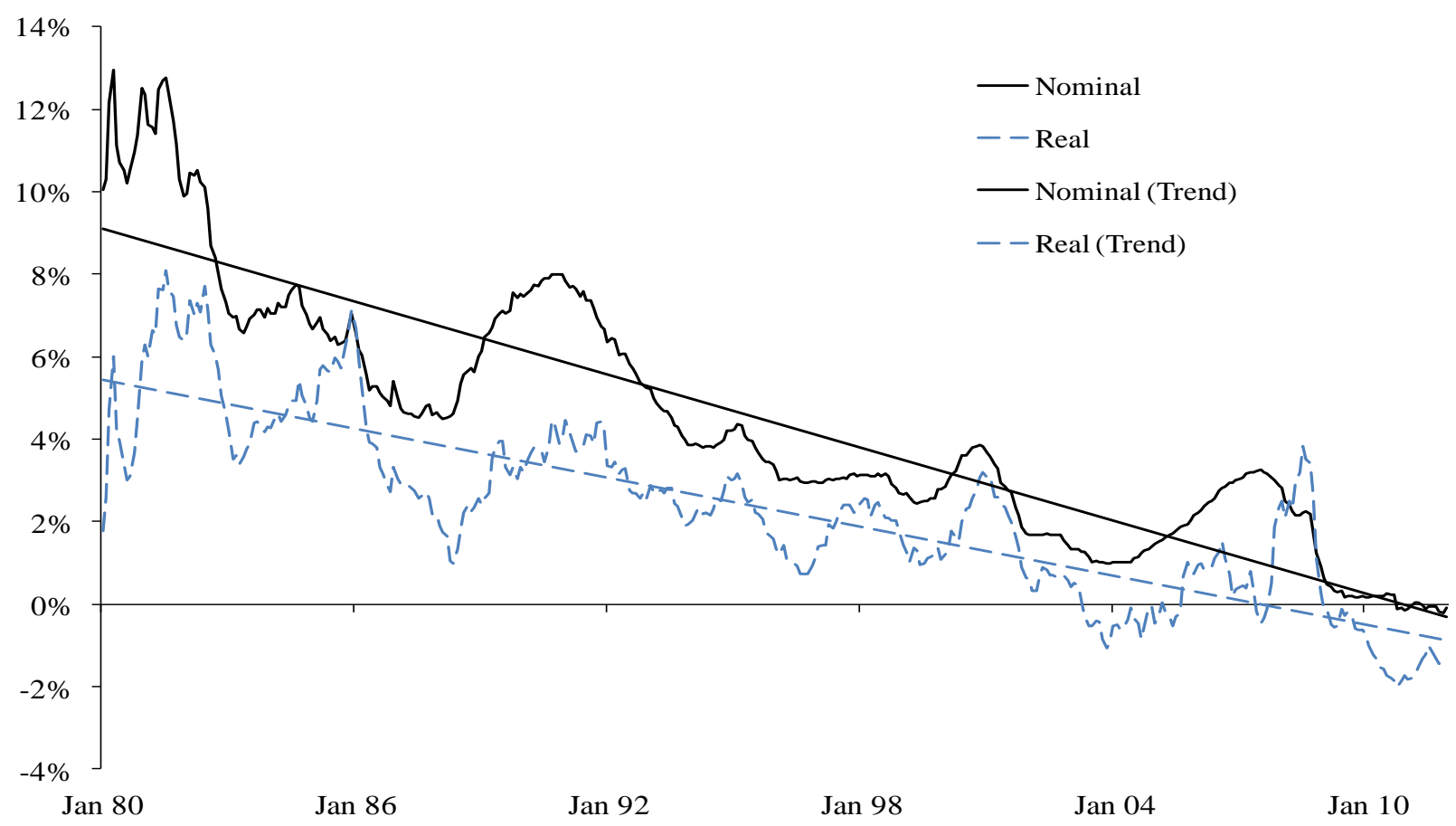

G3=US, Japan and Germany (up to 1998)/euro area

Source: International Monetary Fund (IMF), via Datastream, 2013.

The common trend of structurally declining interest rates and quasi-synchronised inflation of central bank balance sheets in all large industrial countries raises the question of the interdependence of monetary policy making. Prior to the breakdown of the Bretton Woods system, it was argued that the decoupling from the US dollar would enable countries such as Germany and Japan to fit their monetary policy decisions with domestic macroeconomic 
needs in the face of price and wage rigidities (Friedman 1953). However, Figures 1 and 2 suggest that in a financially globalised world, the monetary policy decisions of the large industrialised countries have remained interdependent.

For instance, monetary policy making in Japan has remained strongly dependent on the appreciation pressure on the Japanese yen, with yen appreciation being responded to by (partially massive) foreign exchange intervention or outright interest rate cuts (Goyal \& McKinnon 2003). For the European Central Bank, the notion has also emerged that its interest rate decisions would tend to follow those of the Federal Reserve, particularly since the southern European countries have proven to be vulnerable to euro appreciation (Belke \& Gros 2003).

Figure 2: G3 Monetary Bases as Percent of Gross Domestic Product (GDP)

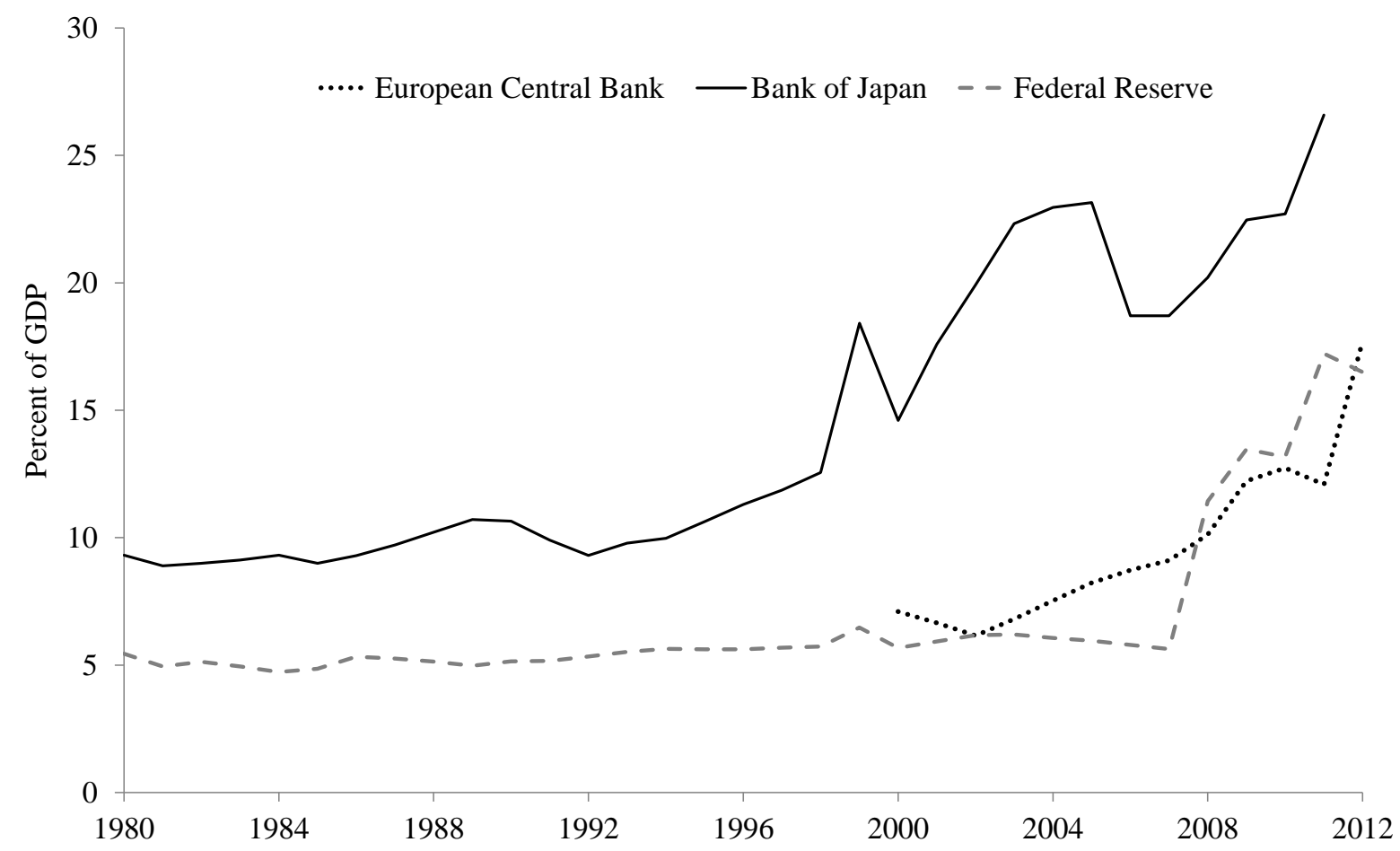

Sources: World Economic Outlook (WEO), European Central Bank and Eurostat, 2013. 


\section{$3 \quad$ Monetary Policy Repercussions on Periphery Countries}

In an asymmetric world monetary system, monetary policy decisions of central banks issuing international currencies (Federal Reserve, European Central Bank, Bank of Japan) have global implications. Outside of Europe, the world is on a US dollar standard (McKinnon 2013); international trade - including the burgeoning intra-industry trade within regions - is mainly invoiced in dollars. The dollar is the dominant means of settling international payments among banks and is the principal reserve and intervention currency used by governments for smoothing exchange rate fluctuations. Whereas the US remains inactive in the foreign exchange market, the countries at the periphery of the world dollar standard peg their exchange rates - more or less tightly - to the dollar to reduce transaction costs for international trade and capital flows. On the other hand, in Europe, the euro has acquired the role of a regional currency.

This asymmetric nature of the world monetary system is reflected in asymmetric capital market structures. Capital markets in the countries issuing international currencies are highly developed, offering a wide range of investment opportunities at all terms of maturities. Transaction costs are low, and instruments to hedge foreign exchange risk are available. In contrast, in emerging markets and developing countries, capital markets are underdeveloped and fragmented (Eichengreen \& Hausmann 1999). Transaction volumes are small, and investment opportunities are limited, particularly at the long end of the yield curve. Instruments to hedge foreign exchange risk are rare and costly. With foreign liabilities and assets being denominated in foreign currencies (dollars and euros), governments stabilise exchange rates against the international anchor currencies to contribute to a stable macroeconomic performance (McKinnon \& Schnabl 2004). 


\subsection{Capital Inflows and Exchange Rate Stabilisation in Emerging Markets}

The structural decline of interest rates in the large industrialised countries issuing international currencies has triggered the growing influx of both portfolio investment and foreign direct investment (FDI) into an increasing number of emerging market economies. With returns being depressed towards historically low levels in the developed financial markets, a 'hunt for yield' has set in. Carry traders have used low-cost financing opportunities in the large industrialised countries to profit from the higher returns in emerging markets, where (linked to the buoyant capital inflows) risk has decreased in two ways.

First, given that interest rates in the large industrialised countries are expected to fall further or continue to be low, exchange rate expectations for emerging market currencies can be assumed to become tilted towards appreciation. This corresponds to a quasi-insurance mechanism for currency risk. Second, the persistent capital inflows into emerging markets are equivalent to a stabilisation fund; as interest rates decline, investments increase, growth accelerates and government revenues increase. Default risk becomes structurally reduced as a (kind of self-fulfilling) pull factor for capital inflows.

Since the turn of the millennium, the buoyant capital inflows into emerging market economies have led to dramatically accelerating foreign reserve accumulation, independent from the exchange rate regime due to a persistent 'fear of floating' (Calvo \& Reinhart 2002). In the case of tight (dollar or euro) pegs, interest rate cuts in the anchor countries have led to quasi-automatic reserve accumulation in the periphery countries. In the case of soft pegs and flexible exchange rates, the expansionary monetary policies of the large industrialised countries have increased the probability of discretionary dollar or euro purchases that are dependent on the negative growth effects of the appreciation of periphery currencies. ${ }^{8}$

\footnotetext{
${ }^{8}$ Concerning the impact of appreciation on emerging market economies with foreign currency-denominated net foreign assets, such as China, see McKinnon and Schnabl (2004). China provides an example of one-way bets on the controlled appreciation path being reflected in high foreign reserve accumulation. If economic agents can circumvent the inbound capital controls to invest at a higher interest rate in China, large arbitrage profits (positive Chinese-US interest differential plus yuan appreciation versus the dollar) can be realised.
} 
Under the benign liquidity conditions in the large industrialised countries, a competitive attraction of speculative capital inflows can emerge. With periphery countries being subdivided into countries with tight exchange rate pegs and freely floating exchange rates, carry traders can realise low-risk speculation profits by investing in freely floating currencies with quasi-persistent appreciation expectations. Countries with more flexible exchange rates would attract more capital inflows and therefore would experience stronger appreciation pressure, which would increase the likelihood and scale of foreign reserve accumulation.

\section{Figure 3: Global Foreign Reserve Accumulation}

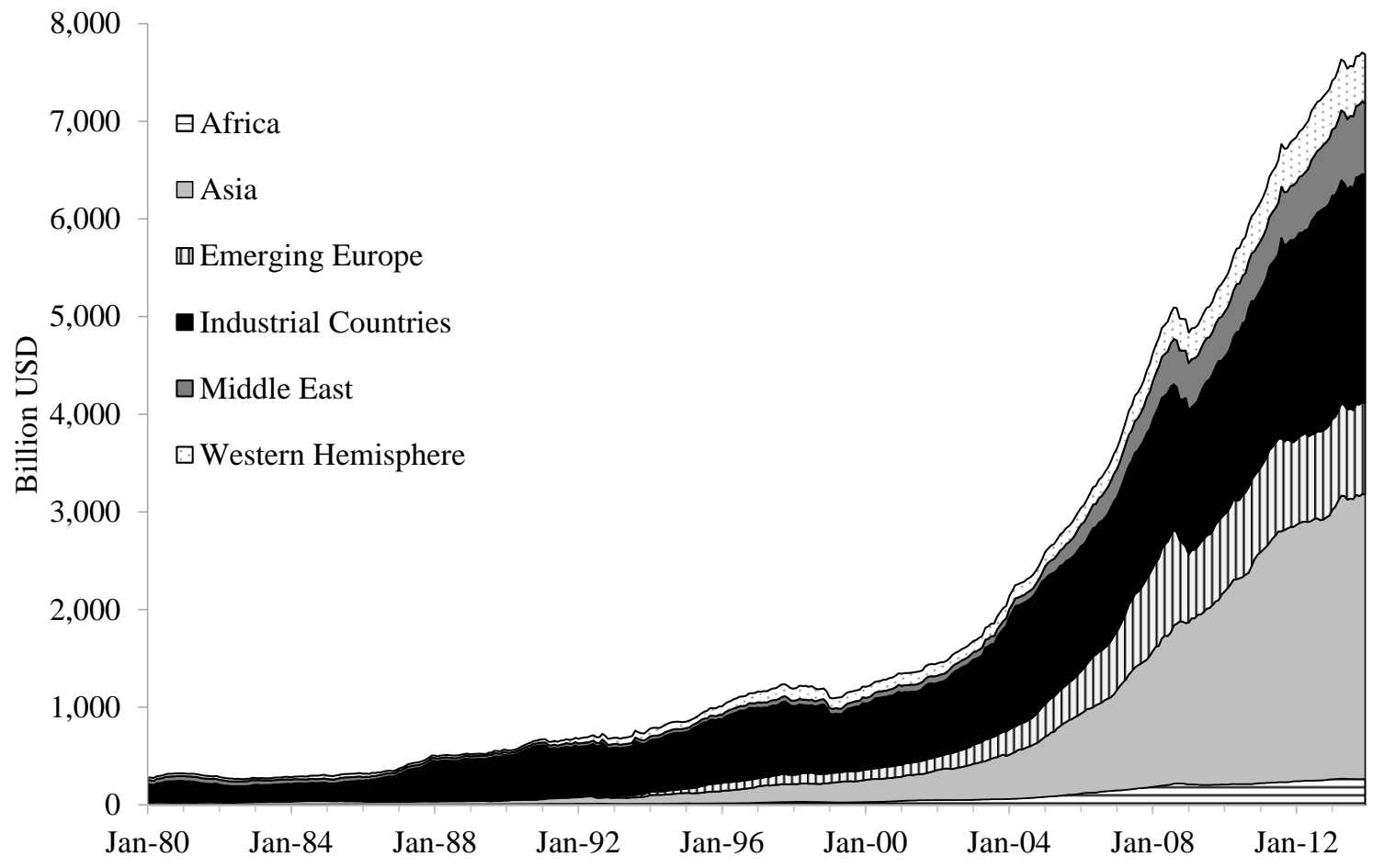

Sources: IMF, IFS, 2014.

Alternatively and complementarily to foreign exchange intervention, interest rate cuts can shield off speculative capital inflows. The underlying monetary expansion is often performed based on the acquisition of foreign assets, as domestic capital markets are shallow. Figure 3 shows the resulting dramatic increase in foreign reserve holdings of emerging 
markets, developing countries and smaller industrialised countries. As Rey (2013, p. 1) put it, "the global financial cycle transforms the trilemma into a "dilemma" or an "irreconcilable duo": independent monetary policies are possible if and only if the capital account is managed'.

\subsection{Monetary Expansion and Credit Booms in Emerging Markets}

If unsterilised, the reserve accumulation of emerging markets' central banks goes with a respective expansion of base money, a decline in interest rates and possibly a credit boom (Corsetti et al. 1999). For internationally integrated capital markets, Figure 4 presents a partial equilibrium model of the impact of monetary expansion in a large industrialised country on international borrowing as source of an unsustainable credit boom in a periphery country. The model can be regarded as an open economy version of the overinvestment theories by Mises (1912) and Hayek (1929 [1976]), as presented in section 2.

We assume that there are two types of economies with different planned savings and investment. The large industrialised country (centre) has higher planned savings than investment $\left(S_{1}^{c}>I_{1}^{c}\right)$. It is the creditor in international capital markets, with the gap between savings and investment being equivalent to the capital export $\left(C X_{1}^{c}\right) \cdot{ }^{9}$ The periphery ${ }^{10}$ has higher investment than savings $\left(I_{1}^{d}>S_{1}^{d}\right)$. It is the capital importer $\left(C M_{1}^{d}\right)$, i.e., the debtor in international capital markets. The international capital market is cleared at the global capital market interest rate $i_{c_{1}}^{w}$, which is equivalent to the national capital market interest rate $\left(i_{c_{1}}^{w}=i_{c_{1}}^{c}=i_{c_{1}}^{d}\right.$, with $\left.C X_{1}^{c}=C M_{1}^{d}\right) \cdot{ }^{11}$ We further assume an equilibrium in international capital markets, with the global capital market interest rate being equal to the global natural interest

\footnotetext{
${ }^{9}$ Lucas (1990) argued that capital does not always flow from rich to poor countries, e.g., due to capital market imperfections and diverging risk premiums.

${ }^{10}$ In practice, the capital exports of one large creditor country is matched by the capital imports of a group of debtor countries, as in the case of Germany and many smaller European countries.

${ }^{11}$ Note that in line with the balance of payments identity, capital exports and capital imports are equivalent to current account positions with inverse signs, reflecting national preferences for intertemporal savings and consumption.
} 
rate $\left(i_{c_{1}}^{w}=i_{n_{1}}^{w}\right)$. Central bank rates are equal to national and global capital market interest rates, as well as the global natural interest rate $\left(i_{c b_{1}}^{c}=i_{c_{1}}^{c}=i_{n_{1}}^{w}=i_{c_{1}}^{w}=i_{c_{1}}^{d}=i_{c b_{1}}^{d}\right)$.

Due to the asymmetric nature of the world monetary system, we assume that the global interest rate is determined by the centre central bank. If the central bank in the centre (creditor) lowers the policy rate (below the global natural interest rate) to $i_{c b_{2}}^{c}$ to promote domestic investment and growth, the financial sector will create additional credit $\Delta C_{1}^{c}$ (as in Garrison 2004). The credit expansion mimics an increase in planned savings, modelled by a shift of the savings curve to the right. The global capital market interest rate falls from $i_{c_{1}}^{w}$ to $i_{c_{2}}^{w}$. The capital exports (imports) of the creditor (debtor) increase to $C X_{2}^{c}$.

Figure 4: International Transmission of a Credit Boom

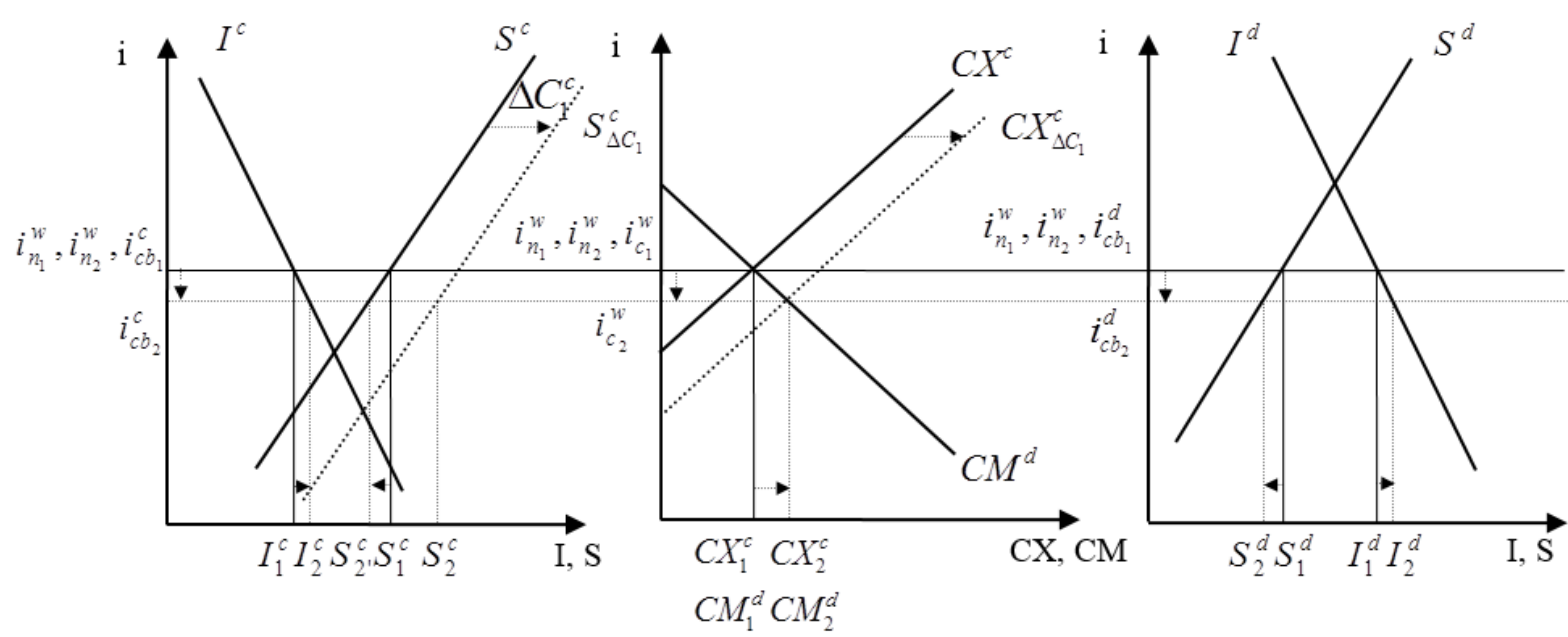

Given the lower interest rates, new investment projects are started. Investment activity increases from $I_{1}^{c}$ to $I_{2}^{c}$ in the centre (creditor) economy and from $I_{1}^{d}$ to $I_{2}^{d}$ in the periphery (debtor) economies. Planned savings fall to $S_{2^{\prime}}^{c}$ in the creditor (centre) economy and to $S_{2}^{d}$ in the debtor (periphery) economies. The term $S_{2}^{c}$ represents the credit supply in the creditor 
economy $\left(S_{2}^{c}=S_{2}^{c}+\Delta C_{1}^{c}\right)$ at $i_{c_{2}}^{w}$. Rising capital exports are reflected in a growing gap between savings and investment $\left(=S_{2^{\prime}}^{c}+\Delta C_{1}^{c}-I_{2}^{c}=S_{2}^{c}-I_{2}^{c}>>0\right)$ in the centre (creditor) economy and $\left(I_{2}^{d}-S_{2}^{d}>>0\right)$ in the debtor economy.

Because planned savings have not increased with the credit expansion but have fallen to $S_{2^{\prime}}^{c}+S_{2}^{d}$, the global capital market interest rate is below the global natural interest rate, $i_{c_{2}}^{w}<i_{n_{2}}^{w}=i_{n_{1}}^{w}$. A global disequilibrium between savings and investment has emerged, which accounts for the difference between $I_{2}^{c}+I_{2}^{d}$ and $S_{2^{\prime}}^{c}+S_{2}^{d}$. The decline of global interest rates below the natural rate triggers (over-)investment with lower expected marginal returns, as modelled in section 2. The default risk of investment increases if (given resource constraints) the global capital market rate should return to the global natural rate. ${ }^{12}$

In line with Figure 4, interest rate levels in emerging market economies (for instance, in East Asia, Latin America and Central and Eastern Europe) have followed the downward trend observed in large industrialised countries (albeit at different degrees and remaining at higher levels) (Figure 5). The question of whether the capital inflows and interest rate cuts will trigger credit and overinvestment booms (as modelled in Figure 4) hinges on the amount of capital inflows, the extent of monetary expansion and the degree of credit growth originating from foreign reserve accumulation.

Because both goods and capital markets in emerging markets are small and underdeveloped, compared to those of the industrialised countries, the absorption capacity of capital markets with respect to monetary expansion and growing credit to the private sector is smaller than those of industrialised countries (McKinnon \& Schnabl 2014). This implies that

\footnotetext{
${ }^{12}$ No credit boom (increase in investment) may emerge in the centre economy despite interest rate cuts. This can be the case in the aftermath of a financial crisis, when investors and banks do not expect an economic recovery despite easy liquidity conditions, as in Japan's case after its bubble economy burst. A low interest rate elasticity of domestic investment would correspond to a close to vertical investment curve $I_{2}^{c}$ in Figure 4. After the centre economy's central bank has lowered policy rates, the additional credit is exported entirely. This amplifies the (potential) credit and overinvestment boom of the periphery.
} 
in case of monetary expansion in centre countries, inflation and asset prices will tend to rise faster in the emerging market economies. The credit boom elasticity of monetary easing is larger.

\section{Figure 5: Interest Rates in G3 and Selected Emerging Market Country Groups}

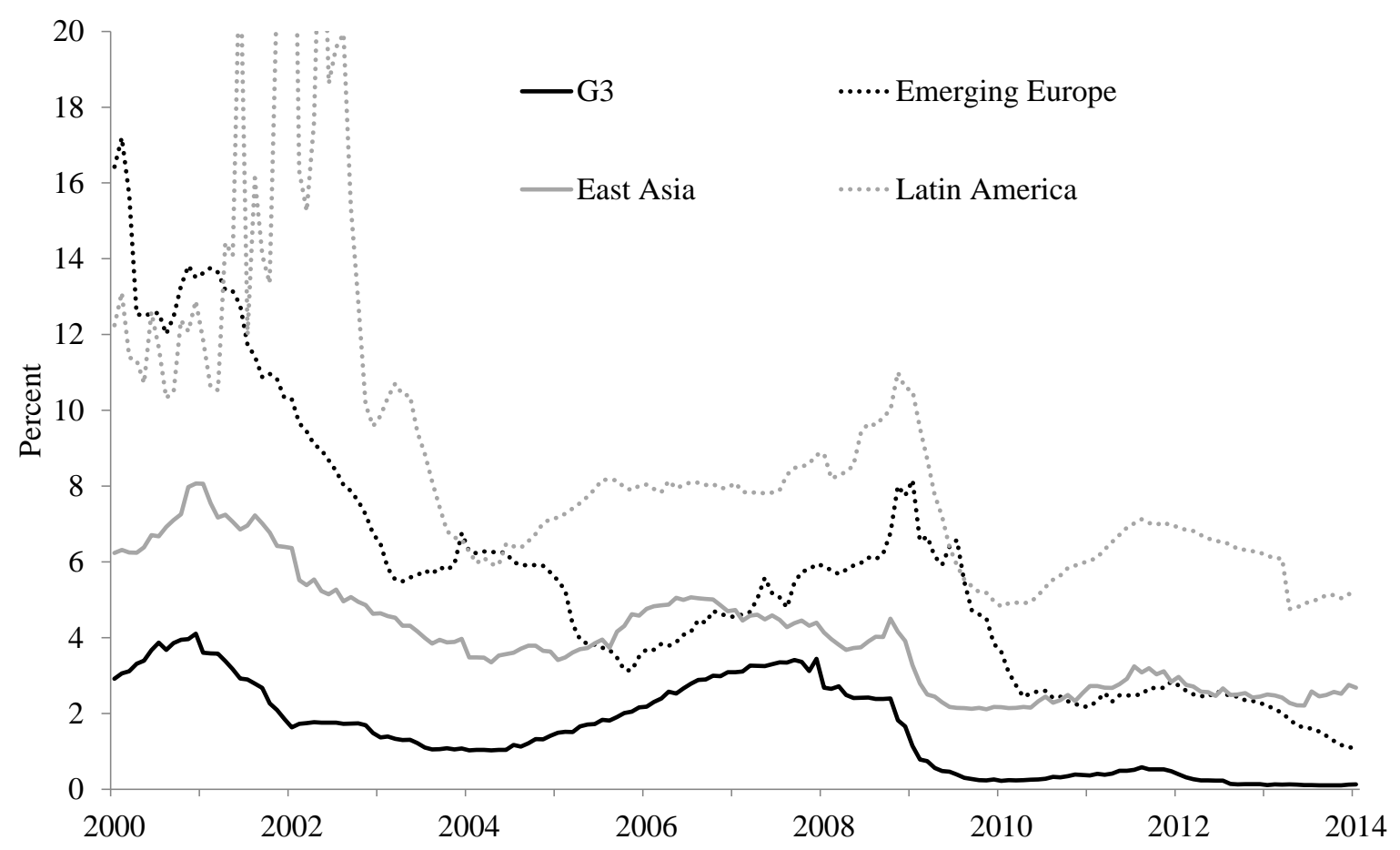

Arithmetic averages. Emerging Europe comprises the new member states of the European Union (EU), excluding Cyprus and Malta. Latin America includes Argentina, Brazil, Chile, Colombia, Mexico and Peru. East Asia consists of China, Thailand, Hong Kong, Indonesia, the Philippines, Malaysia, Singapore and South Korea.

Sources: IMF, IFS, 2014.

\subsection{Sterilisation Policies and Capital Controls in Emerging Markets}

To prevent consumer and asset price inflation from increasing in the face of buoyant capital inflows, central banks in emerging markets may feel forced to sterilise the monetary effects of excessive foreign reserve accumulation. Figure 6 shows the balance sheets of the central banks of China and Estonia. In the balance sheets of both the People's Bank of China and Eesti Pank, foreign assets have substantially grown since 2001. In China, the pronounced 
increase of foreign reserve has triggered extensive sterilisation operations to contain undue credit growth.

Principally, there are two sterilisation techniques (Löffler et al. 2010). In market-based sterilisation, the central bank sells domestic currency bonds to financial entities to reduce their liquidity holdings. The downside is that upward pressure on the open-market, domestic interest rate induces even greater inflows of hot money, with sterilisation costs (potential central bank losses) becoming substantial. Nonmarket-based sterilisation raises reserve requirements on bank deposits so that less bank credit can be issued for any given increase in base money. Since usually the remuneration for required reserves is low or even zero, the sterilisation costs are minimised. The disadvantage is that sterilisation costs are shifted to commercial banks, which become restricted in their function as financial intermediaries. Refinancing via the central bank may be substituted by international borrowing, which again induces additional capital inflows.

The upper left panel of Figure 6 shows the sterilisation instruments of the People's Bank of China, with negative signs on the liability side of the central bank's balance sheet. The lower left panel shows the interest rates on sterilisation instruments. The People's Bank of China has issued central bank bonds to a certain extent to sterilise the liquidity effects of reserve accumulation. The interest rate paid on central bank bills is close to the money market rate, indicating that the remuneration has generally been market based (lower left panel, Figure 6). In contrast, as reflected by fast-growing bank deposits, required reserves have acquired a dominating role as sterilisation instruments, with the reserve requirement rate being gradually increased. The remuneration rate of reserve requirements is substantially lower than the money market rate, indicating nonmarket-based sterilisation.

To enhance the effectiveness of (nonmarket-based) sterilisation operations, capital controls restricting inward flows are necessary to shield off additional capital inflows (McKinnon \& Schnabl 2014). Whereas in China, FDI inflows have become widely 
liberalised, but portfolio and external bank inflows are tightly controlled (Ma \& McCauley 2007). In Brazil, Tobin-type taxes on fixed-income investments, bond and stock purchases and issuance of depositary receipts were imposed to curtail capital inflows (Reinhart 2012). Nevertheless, the high degree of reserve accumulation in most emerging markets indicates that the effectiveness of capital controls has been limited.

Figure 6: Central Bank Balance Sheets and Interest Rates in China and Estonia

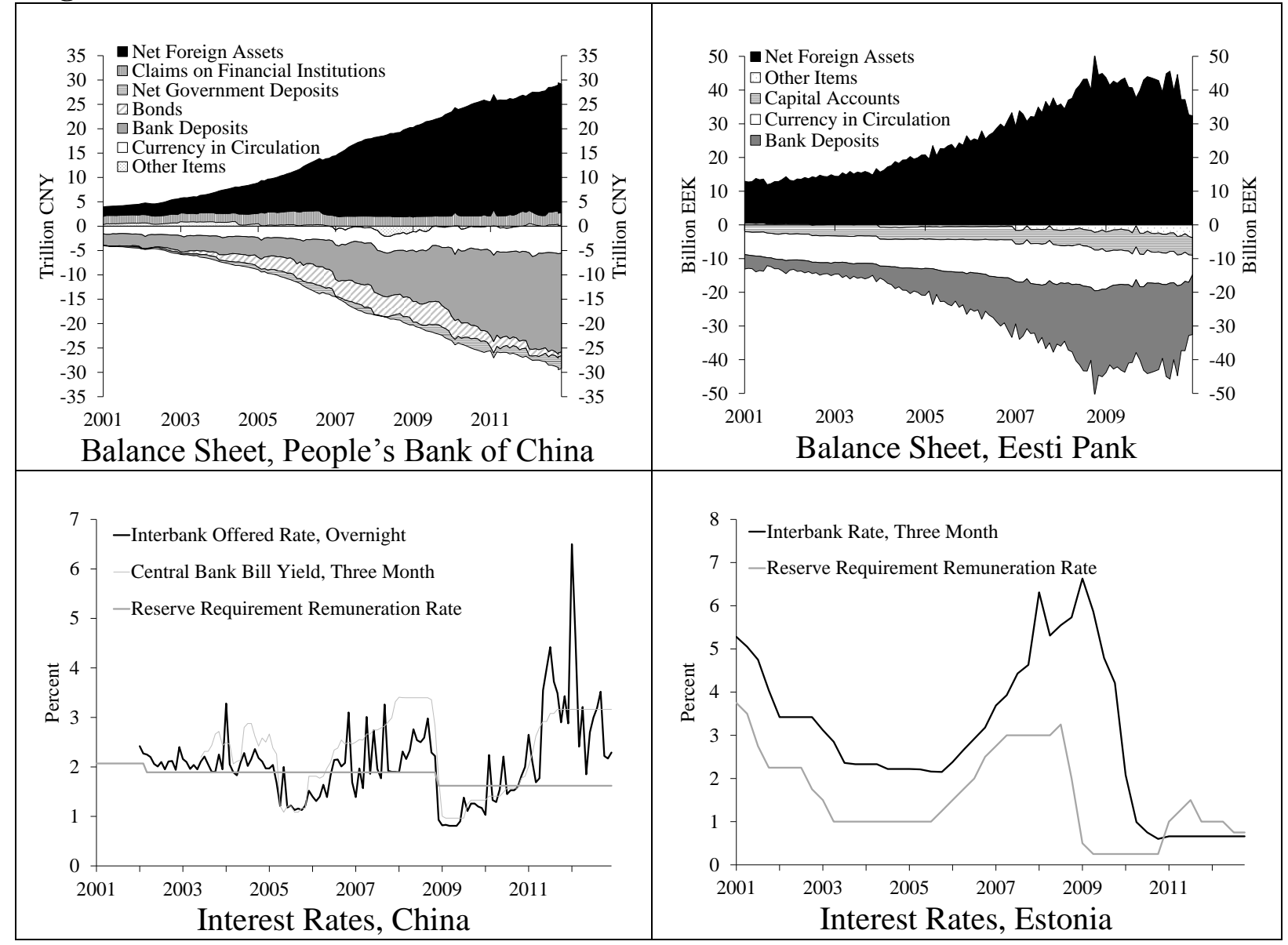

Sources: IMF, IFS, 2014.

In contrast, in Estonia the large-scale, foreign reserve accumulation resulting from capital inflows remained widely unsterilised. A different institutional setting of the currency board arrangement, as well as the provision of free capital flows within the EU, neither allowed for nonmarket-based sterilisation nor for capital controls. In contrast to China, the reserve requirement rate and the basis for reserve requirement holdings remained widely unchanged during the credit boom. Therefore, the substantial increase of bank deposits (and 
currency in circulation) was available for credit growth in Estonia, with the reserve requirement remuneration rate following the money market (interbank) rate (indicating market-based remuneration).

A similar phenomenon could be observed in the southern periphery of the euro area (the later crisis countries), where - per definition - the capital inflows remained unsterilised, feeding into unsustainable credit growth, stock and real estate market booms, as well as inflation above the euro area average (Schnabl \& Wollmershäuser 2013). Similarly, during the 1990s, the capital inflows into the Southeast Asian later crisis countries (originating in the low interest rate policy of the Bank of Japan in response to the post-bubble recession) remained widely unsterilised, causing an unsustainable credit boom, rising current account deficits and growing foreign currency-denominated, international debt.

The different degrees of sterilisation had different feedback effects on the centre countries. Given the high degree of sterilisation at the periphery of the informal dollar standard since the turn of the millennium (particularly in East Asia as a lesson from the Asian crisis), the inflationary pressure in both the periphery and the centre was supressed. The inflationary feedback effects on the centre country in the form of rising prices of imported goods (for instance, as measured by the US price inflation of imports from China) remained contained. This implies that the absorption of liquidity at the periphery postponed the monetary tightening in the centre country, where the subprime market bubble emerged.

The inflationary effects on some euro area countries were compensated by lower inflation within other euro area countries (e.g. Germany), since the European Central Bank targets an average inflation rate for the euro area as a whole. The inflationary effects of the booming European countries outside the euro area can be assumed to have driven up euro area inflation via import prices (with their economic weight being comparatively small).

Figure 7 shows the implications of different sterilisation strategies (after the turn of the millennium) for credit growth and the current account positions. In East Asia, the sterilisation 
process can be seen as a lesson from the 1997/1998 Asian crisis, which had been caused by an unsustainable credit boom. As shown on the left side panels, credit growth has generally reflected GDP growth since the turn of the millennium. Only with the Federal Reserve's three generations of quantitative easing from 2007/2008 onwards we observe a new increase in credit to the private sector as a percentage of GDP. Given the relatively restrictive monetary policy stances relative to the US, current account positions have tended to improve. Only with the re-emerging growth of credit to the private sector since 2008, has the average current account surplus of East Asia declined.

Figure 7: Credit Growth and Current Accounts in East Asia and Emerging Europe

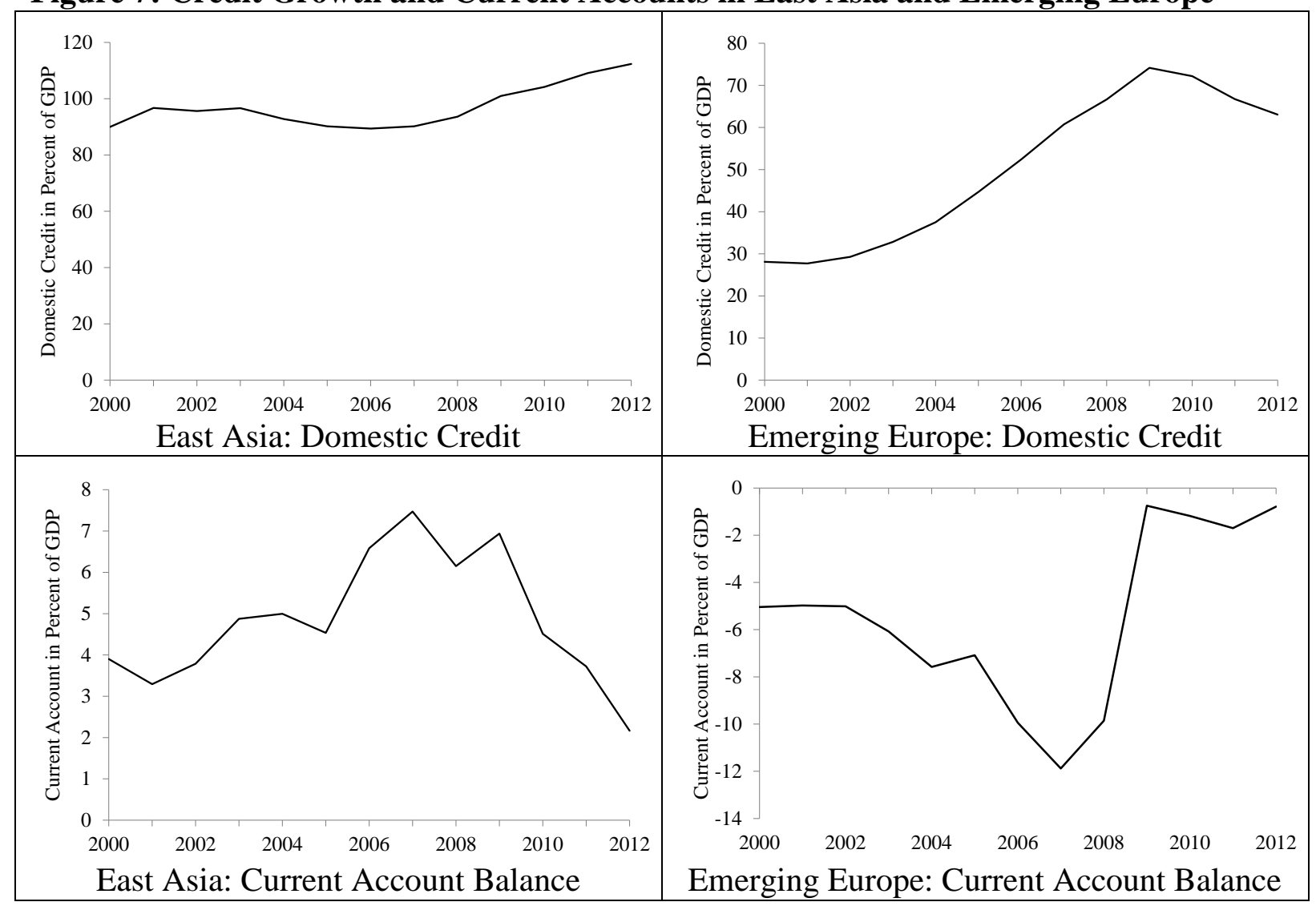

Arithmetic averages.

Source: World Development Indicators (WDI), 2014.

In contrast, as shown on the right-hand panels of Figure 7, credit to the private sector as a percentage of GDP dramatically increased in the Central and Eastern European new member states of the EU after the turn of the millennium. This process went along with a gradual loss 
of competitiveness and strongly increasing current account deficits. The rising foreign currency-denominated debt became the breeding ground for the crisis starting in 2008. A similar process took place in the southern and western peripheries of the euro area (see e.g. Schnabl \& Wollmershäuser 2013).

\section{Periphery Crisis and Repercussions on the Centre}

The monetary overinvestment theories of Mises (1912) and Hayek (1929 [1976]) suggest that a crisis occurs when central banks tighten credit by increasing the central bank interest rate. Alternatively, the private banking sector tightens credit due to changing economic sentiment. Emerging markets that have generally abstained from sterilisation and therefore have accumulated larger stocks of foreign currency-denominated international debt tend to be more vulnerable to a global tightening of liquidity.

\subsection{Policy Reversal and Periphery Crisis}

Figure 8 illustrates the policy reversal in the centre (creditor) economy. When the central bank in the centre tightens money supply, the banking sector has to reduce the credit exposure, for instance, by $\Delta C_{2}^{c}$. The central bank rate increases to $i_{c b_{3}}^{c}$, which is, for instance, equivalent to the global natural interest rate. ${ }^{13}$ The savings curve shifts back to its initial position $\left(S_{3}^{c}=S_{1}^{c}\right)$. Capital exports from the centre to the periphery economies fall from $C X_{2}^{c}$ to $C X_{3}^{c}$. Global capital market interest rates rise to $i_{c_{3}}^{w}$, along with the centre policy rate.

This lifts the threshold for the profitability of investment projects. Structural distortions are cleared, as investments with expected returns below the natural interest rate have to be dismantled. Investment in the centre (creditor) economy falls to $I_{3}^{c}$ and investment

\footnotetext{
${ }^{13} \mathrm{We}$ assume that due to the asymmetry of the world monetary system, the global interest rate is determined by the centre central bank.
} 
in the periphery (debtor) to $I_{3}^{d}$. Planned savings increase from $S_{2^{\prime}}^{c}$ to $S_{3}^{c}$ in the centre (creditor) economy and from $S_{2}^{d}$ to $S_{3}^{d}$ in the periphery (debtors). Global planned savings and investment are balanced again, as the global capital market rate is equal to the global natural interest rate. $^{14}$

\section{Figure 8: Policy Reversal}

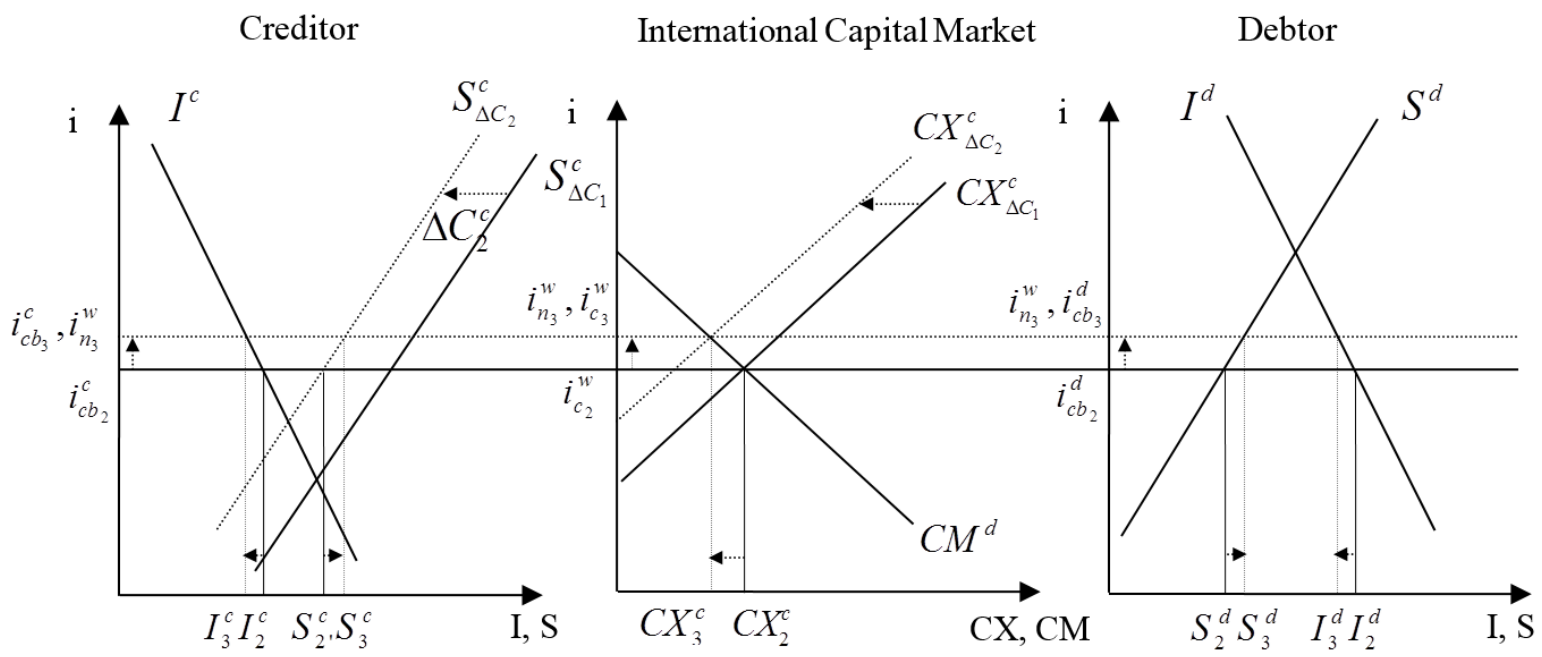

A destabilising effect of tightening credit conditions by centre central banks could be observed prior to the European financial and debt crisis in many central and eastern European countries, as well as in the later crisis countries of the euro area. Currently, announcements of a phasing out of quantitative easing by the Federal Reserve System have triggered instability in many emerging market economies, including India, Brazil, South Africa and Turkey. In contrast, the economic turnaround in the Southeast Asian countries prior to the Asian crisis was triggered by a changing economic sentiment concerning the sustainability of the Southeast Asian economic miracle, which corresponded to a credit tightening originating in capital markets.

\footnotetext{
${ }^{14}$ Note that in this case, planned savings are equivalent to overall savings.
} 


\subsection{Crisis and Fragmentation of International Capital Markets}

If capital markets anticipate an economic turnaround in the emerging markets, a flight to the safe havens sets in. This imposes even tighter monetary conditions on the emerging markets. When investment projects in the periphery economies are dismantled, the risk premium in international borrowing rises. If linked to capital outflows, a periphery country's currency would depreciate, and its foreign currency debt would be inflated in terms of the domestic currency (Corsetti et al. 1999). With financial markets anticipating the joint default of the periphery's banking sector, capital flows to the periphery dry up.

In Figure 9, capital exports of the centre shift from $C X_{3}^{c}$ to $C X_{4}^{c}$, i.e., to zero. ${ }^{15}$ As the periphery is cut off from international capital markets, its capital market interest rate shifts upward towards the self-sufficiency rate $i_{c_{4}}^{d}$, which is equivalent to the periphery's domestic natural interest rate $i_{n_{4}}^{d}$. In the face of crisis, the periphery's central bank rate is lifted towards $i_{c b_{4}}^{d}$ to keep the exchange rate stable and to countersteer capital outflows. (Dollar sales and purchases of domestic currency correspond to monetary tightening.)

\section{Figure 9: Crisis and Disintegration of International Capital Markets}

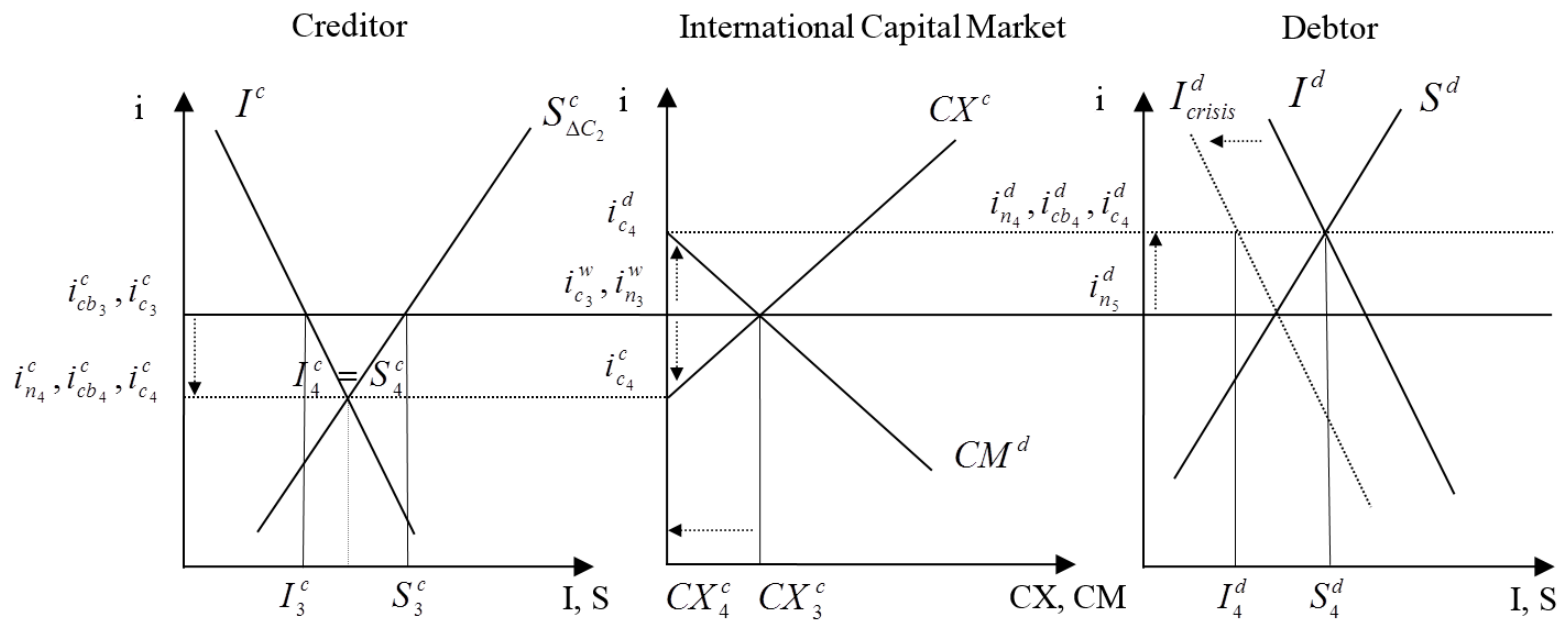

\footnotetext{
${ }^{15}$ For simplicity, we assume that capital exports of the centre country become zero. In reality, the capital flight to the safe haven tends to turn the emerging market's (centre country's) financial account to positive (negative).
} 
When liquidity in international capital markets dries up, the cumulative downward process in the periphery accelerates. Investment demand falls. In Figure 9, the investment curve shifts from $I^{d}$ to $I_{c r i s i s}^{d}$, and the natural interest rate declines to $i_{n_{5}}^{d}$. In this situation, holding central bank interest rates high at $i_{c b_{4}}^{d}$ is equivalent to a type 2 monetary policy mistake, which amplifies the downturn, with planned savings being larger than investment $\left(S_{4}^{d}>I_{4}^{d}\right)$.

With capital remaining in the safe haven of the centre country, the centre's domestic natural interest rate declines to $i_{n_{4}}^{c}$. If the central bank aims to avoid a type 2 monetary policy mistake by holding the interest rate unchanged at $i_{c b_{3}}^{d}$, it will allow the capital market rate to drop to $i_{c_{4}}^{c}$ by reducing the central bank rate $i_{c b_{4}}^{c}$ towards the domestic natural rate $i_{n_{4}}^{c}$. At the lower interest rate, planned investment rises from $I_{3}^{c}$ to $I_{4}^{c}$, while planned savings fall from $S_{3}^{c}$ to $S_{4}^{c}$ (balancing investment).

\subsection{Feedback Effects on Centre Countries and Monetary Policy Rescue Measures}

If the periphery central bank aims to avoid a type 2 monetary policy mistake by cutting the central bank interest rate towards the domestic natural interest rate $i_{n_{5}}^{d}\left(=i_{c b_{5}}^{d}=i_{c_{5}}^{d}\right.$ ) (or if foreign reserves are depleted), the resulting depreciation of the domestic currency inflates the foreign currency-denominated debt in terms of the domestic currency. The financial sector collapses. This causes painful contagion effects on the centre's financial sector and constitutes an incentive for the centre central bank to cut interest rates below the (domestic) natural interest rate $i_{n_{4}}^{c}$ to contain a potential financial crisis.

In East Asia and Europe, we could observe that crises in periphery countries have such negative feedback effects on centre countries. In the 1997/1998 Asian crisis, Japanese banks (which were already ailing from the consequences of the bursting Japanese bubble) suffered from the new credit default in Southeast Asia. The credit defaults, together with Japanese 
enterprises' declining exports to Southeast Asia, triggered the sharp decline in stock prices, which became the focal point of the 1998 Japanese financial crisis (Hoffmann \& Schnabl 2011). The crisis forced the Bank of Japan to cut interest rates further to zero and to embark on quantitative easing.

In Europe, the crisis inside and outside the EMU (including the simultaneous crisis in the US subprime market) had painful contagion effects on the northern European banks, particularly the German banking sector. The tremendous credit exposure of mainly northern European banks to ailing banking sectors at the periphery of the EMU made monetary policy rescue measures necessary. These comprised interest rate cuts towards zero, several measures of quantitative easing, the accumulation of crisis countries' government bonds in the ECB's balance sheets, as well as an announcement that everything necessary would be done to save the euro.

In Figure 10, the centre's central bank pushes the central bank interest rate down to $i_{c b_{5}}^{c}$ (below the domestic natural interest rate $i_{n_{4}}^{c}$ ) by injecting additional credit $\Delta C_{3}^{c}$. The aim is to restore confidence in financial markets and prevent a potential domestic financial collapse and a subsequent credit crunch. The benign liquidity conditions shrink the risk premium and reanimate capital flows to the periphery. The capital export curve shifts to $C X_{5}^{c}$, as international capital markets start to reintegrate.

As international lending picks up, capital outflows put an upward pressure on domestic interest rates in the centre country towards $i_{c_{5}}^{w}$. As at $i_{c_{5}}^{w}$, the centre's investment would fall again to $I_{5}^{c}\left(<I_{4}^{c}\right)$, the centre central bank moves towards further monetary expansion to keep the interest rate at $i_{c b_{5}}^{c}=i_{c_{5}}^{c}=i_{c_{6}}^{w}$. The additional credit expansion $\Delta C_{4}^{c}$ shifts the capital supply curve to $S_{\Delta C_{4}}$ (while planned savings fall). As the global natural interest rate is not affected by the credit expansion $\left(i_{n_{5}}^{w}=i_{n_{6}}^{w}\right)$, the global capital market 
interest rate is now far below the global natural interest rate $i_{c_{6}}^{w}=i_{c b_{6}}^{c}<<i_{n_{6}}^{w}$. At the lower global capital market rate $i_{c_{6}}^{w}$, capital exports strongly increase from $C X_{5}^{c}$ to $C X_{6}^{c}$, and investment grows further to $I_{6}^{d}\left(>I_{5}^{d}\right)$ in the periphery and to $I_{6}^{c}\left(>I_{4}^{c}>I_{5}^{c}\right)$ in the centre country. Monetary policy has sown the seeds of a new, even larger overinvestment cycle.

Figure 10: Excessive Monetary Policy Response

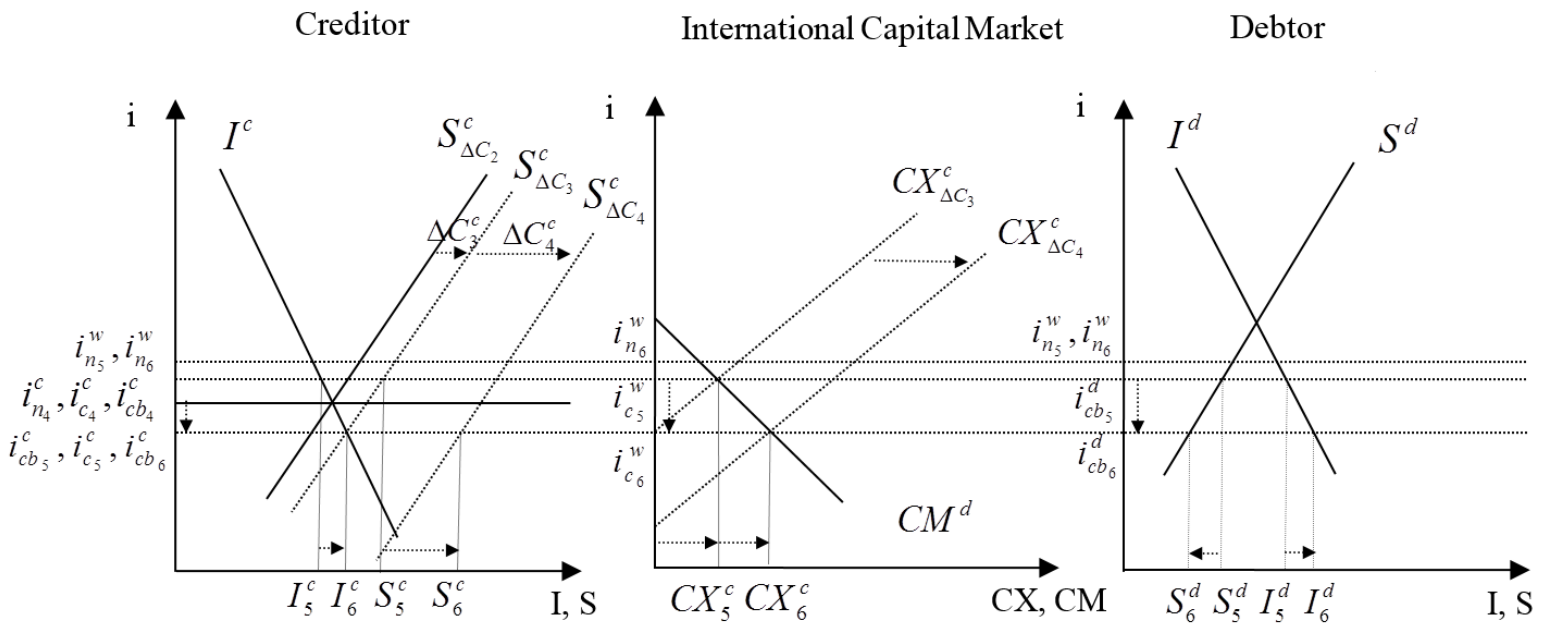

\section{Outlook: The Low Interest Rate Trap}

We have shown that asymmetric interest rate cuts and quantitative easing in large industrialised countries increase the likelihood and scope of boom-and-bust cycles in emerging market economies. We have further explained that the international transmission of monetary policies from the centre to the periphery of the world monetary system and its feedback effects on the centre may have contributed to asymmetric monetary policy patterns, as observed in the large industrialised countries (i.e., hesitant interest rate increases during boom periods and decisive cuts in crisis periods).

In an asymmetric world monetary system, the absorption of inflationary pressure at the periphery constitutes an incentive for the centre central bank to further expand monetary accommodation, possibly beyond what ensures a stable, global macroeconomic development. 
Due to rising international capital flows the emerging markets have grown in importance for financial stability of the centre countries. (Potential) periphery crises have become a threat to financial stability in the centre economies. (Inter alia) to prevent financial turbulence in the emerging markets, policymakers seem to opt for an overly extended period of low interest rates.

With interest rates having reached the zero-bound in the recent crisis, quantitative easing initiatives aim to tilt interest rates further downwards on the long end of the yield curve. Meanwhile, preventing government default is also seen as a tool to safeguard financial stability. This opens the path towards the persistence of the low interest rate environment via the impact of the prime interest rate cuts and quantitative easing on public debt developments, as most evidently observed in Japan.

The reason is that structurally declining interest rates encourage rising government debt. In Japan, where the crisis has continued since the early 1990s, despite an increase of gross government debt from roughly 60\% of the GDP in 1990 (when the bubble burst) to $240 \%$ in 2014 , the interest rate payments as a share of the general government budget have generally remained constant.

Yet, the higher the level of government debt, the higher will be the pressure on the central bank to keep interest rates close to zero and to reduce the yields on government bonds by unconventional monetary policy measures. The implications are the lock-in effects of low interest rate policies and unconventional monetary policies, i.e., a low interest rate trap. This is even more the case, as any monetary tightening is likely to cause new financial instability, with the cost of the default of financial institutions being shifted to the public sector. The hysteresis of the low interest rate and the high debt environment in the industrialised countries is likely to continue to have destabilising effects on the emerging markets at the periphery of the asymmetric world monetary system. 


\section{REFERENCES}

Belke, Ansgar, and Daniel Gros (2003), 'Does the ECB Follow the Fed', Applied Economics Quarterly 49, 192-210.

Bernanke, Ben (2000), 'Japanese Monetary Policy: A Case of Self-Induced Paralysis?', in R. Mikitani and A. Posen, eds, Japan's Financial Crisis and Its Parallels to U.S. Experience, pp. 149-66. Washington DC: Institute for International Economics.

Bernanke, Ben, and Mark Gertler (2001), 'Should Central Banks Respond to Movements in Asset Prices?', American Economic Review 91 (2), 253-57.

Bernanke, Ben (2004), 'The Great Moderation', Remarks by Governor Ben S. Bernanke at the Meeting of the Eastern Economic Association, Washington, DC, 20 February 2004.

Bernanke, Ben (2014), 'The Federal Reserve: Looking Back, Looking Forward', Speech at the Annual Meeting of the American Economic Association, Philadelphia, Pennsylvania, 3 January 2014.

Blinder, Alan, and Ricardo Reis (2005), 'Understanding the Greenspan Standard', Princeton University Working Paper No. 88. Department of Economics, Center for Economic Policy Studies.

Borio, Claudio, and Piti Disyatat (2011), 'Global Imbalances and the Financial Crisis: Link or no Link?', BIS Working Papers 346.

Buchanan, James, and Richard Wagner (1977 [1999]), Democracy in Deficit: The Political Legacy of Lord Keynes, Indianapolis, IN: Liberty Fund, Reprint 1999.

Calvo, Guillermo, and Carmen Reinhart (2002), 'Fear of Floating', Quarterly Journal of Economics 107 (2), 379-408.

Corsetti, Giancarlo, Paolo Pesenti, and Nouriel Roubini (1999), 'Paper Tigers? A Model of the Asian Crisis', European Economic Review 43, 1211-36.

Draghi, Mario (2014), Introductory Statement to the Press Conference (with Q\&A), Frankfurt am Main, 9 January 2014.

Eichengreen, Barry, and Ricardo Hausmann (1999), 'Exchange Rates and Financial Fragility', NBER Working Paper No. 7418.

Friedman, Milton (1953), 'The Case for Flexible Exchange Rates', Essays in Positive Economics. Chicago University Press.

Friedman, Milton, and Anna Schwartz (1963), A Monetary History of the United States, 1867-1960, Princeton, NJ: Princeton University Press.

Garrison, Roger (2004), 'Overconsumption and Forced Saving in the Mises-Hayek Theory of the Business Cycle', History of Political Economy 36 (2), 323-49.

Goyal, Rishi, and Ronald McKinnon (2003), 'Japan's Negative Risk Premium in Interest Rates: The Liquidity Trap and the Fall in Bank Lending', The World Economy 26, 339-63.

Hayek, Friedrich v. (1929 [1976]), Geldtheorie und Konjunkturtheorie. Salzburg: Philosophia Verlag, Reprint 1976.

Hayek, Friedrich v. (1937 [1989]), Monetary Nationalism and International Stability. Fairfield, NJ: Augustus Kelley Publishers, Reprint 1989.

Hoffmann, Andreas, and Gunther Schnabl (2011), 'A Vicious Cycle of Manias, Crises and Asymmetric Policy Responses - An Overinvestment View', The World Economy 34 (3), 382-403.

Huerta de Soto, Jesus (2009), Money, Bank Credit, and Economic Cycles, $2^{\text {nd }}$ ed. Auburn: Ludwig von Mises Institute.

Iwata, Kazumasa, and Shinji Takenaka (2011), 'Central Bank Balances Sheet Expansion: Japan's Experience', BIS Working Paper No. 66. 
Löffler, Axel, Gunther Schnabl, and Franziska Schobert (2010), 'Inflation Targeting by Debtor Central Banks in Emerging Market Economies', Center for Economic Studies and Ifo Institute (CESifo) Working Paper No. 3138.

Lucas, Robert (1990), 'Why Doesn't Capital Flow from Rich to Poor Countries?', American Economic Review 80 (2), 92-96.

Ma, Guonan, and Robert McCauley (2007), 'How Effective are China's Capital Controls?', in R. Garnaut and L. Song, eds, China: Linking Markets for Growth, 267-89. Canberra: Australian National University Press, Asia Pacific Press and Social Sciences Academic Press.

McKinnon, Ronald (2013), The Unloved Dollar Standard. From Bretton Woods to the Rise of China. New York: Oxford University Press.

McKinnon, Ronald, and Gunther Schnabl (2004), 'The Return to Soft Dollar Pegging in East Asia. Mitigating Conflicted Virtue', International Finance 7 (2), 169-201.

McKinnon, Ronald, and Gunther Schnabl (2014), 'China's Exchange Rate and Financial Repression. The Conflicted Emergence of the Renminbi as an International Currency', CESifo Working Paper No. 4649.

Mises, Ludwig v. (1912), Die Theorie des Geldes und der Umlaufmittel. Leipzig: Duncker und Humblot (available at www.mises.org).

Mishkin, Frederic (2008), 'How Should we Respond to Asset Price Bubbles?', Banque de France Financial Stability Review 12, 65-74.

Posen, Adam (2000), 'The Political Economy of Deflationary Monetary Policy', in R. Mikitani and A. Posen, eds, Japan's Financial Crisis and Its Parallels to U.S. Experience, 194-208. Washington DC: Institute for International Economics.

Reinhart Carmen (2012), 'The Return to Financial Repression', Banque de France Financial Stability Review No. 16.

Revankar, Nagesh, and Naoyuki Yoshino (2008), 'An Empirical Analysis of the Japanese Banking Sector in a Period of Financial Instability', Keio Economic Studies 45, 1-15.

Rey, Hélène (2013), 'Dilemma or Trilemma: The Global Financial Cycle and Monetary Policy Independence'. Mimeo.

Schnabl, Gunther, and Timo Wollmershäuser (2013), 'Fiscal Divergence and Current Account Imbalances in Europe', CESifo Working Paper No. 4108.

Schumpeter, Joseph (1934), The Theory of Economic Development, Transaction Publishers, Reprint.

Stiglitz, Joseph (2010), Freefall: America, Free Markets, and the Sinking of the World Economy. New York and London: W. W. Norton \& Company.

Stokes, Doug (2014), 'Achilles' Deal: Dollar Decline and US Grand Strategy after the Crisis', Forthcoming in Review of International Political Economy.

Summers, Larry (2013), Speech at the IMF Economic Forum, 8 November 2013.

Taylor, John (1993), 'Discretion versus Policy Rules in Practice', Carnegie-Rochester Conference Series on Public Policy 39, 195-214.

Taylor, John (2009), Getting Off Track: How Government Actions and Interventions Caused, Prolonged, and Worsened the Financial Crisis, Stanford, CA: Hoover Institution Press, Stanford University.

von Weizsäcker, Carl-Christian (2011), Public Debt Requirements in a Regime of Price Stability. Max Planck-Institute for Collective Goods, Bonn.

Xiaochuan, Zhao (2009), 'Reform the International Monetary System', BIS Review 41, 1-3. 